\title{
AKUNTANSI PARTAI POLITIK
}

\author{
Kariyoto \\ Jurusan Akuntansi, Sekolah Tinggi Ilmu Ekonomi ASIA, \\ Jl. Soekarno Hatta Rembuksari 1A, Malang \\ email: kariyoto@um.ac.id/NO Telepon:085855526337
}

\section{ABSTRACT}

Accounting for Political Parties. Healthy political parties, credible and capable of running the General Election held in a democratic, honest and fair is the capital of democracy credible. Democracy is a credible government authorized the creation of a solid and authoritative with effective control of the institution legistalif. Credible democracy is not possible without transparency and clear accountability mechanisms for the financing of political activities, both financial and political party financing of the General Election. This financial accountability requires transparency of financial accounting standards for political parties, political party auditing guidelines, and the existence of guidelines, regulations, and procedures for financial reporting on the activities of the General Election campaign for political parties. One of the major problems that arise are the accounting standards. In the meantime, the existing accounting standards, namely Principle of Financial Accounting Standards 45, the accounting standards made for non-profit organization that Indonesia Institute of Accountants (IAI )is also used for political parties. (PSAK) 45 is not sufficient to accommodate the characteristics of different political parties with other nonprofit organizations. Therefore, this study recommends a modification or specific guidelines for financial accounting standard for political parties. This article we hope will encourage various parties, in this Parliament, the Commission, the Supreme Court and the Association of Accounting Indonesia to sit together and agree on specific accounting standards for political parties including campaign funds. This paper hopefully be a reference, although subject to change according to the Law on Political Parties and Elections are currently being discussed in Parliament. Accounting standards in this paper can be a reference to the new legislation. Reflecting the general election of 2009 was the lack of management, accountability and control of financing of political activities. Almost all political parties having problems financing of political activities, including the financing of legislative elections that followed the political campaign. Weak financial systems has led to uncontrolled political money (money politics), which involves almost all political parties in elections.

\section{PENDAHULUAN}

Walaupun ada batasan jumlah dana yang boleh diterima oleh partai politik, namun banyak sekali celah-celah besar yang dimanfaatkan oleh individu-individu atau kelompokkelompok yang berusaha mempengaruhi posisi partai politik lewat sumbangan yang mereka berikan ke parta-partai tersebut. Bahan dasar dari studi ini adalah laporan keuangan partai politik dan laporan dana kampanye yang telah disampaikan kepada Mahkamah Agung dan suatu diskusi kelompok fokus. Selain itu, penulis juga melakukan banyak wawancara 
dengan para akuntan dan ahli politik.

Sehingga hasil studi ini boleh dikatakan merupakan rangkuman dari berbagai pendapat praktisi maupun kalangan ahli dalam bidang keuangan dan perpolitikan. Dari hasil studi ini dapat disimpulkan bahwa laporan keuangan yang disampaikan partai politik, baik laporan dana kampanye maupun laporan tahunan sangat tidak memadai dan paparannya tidak lengkap. Sedangkan laporan tahunan tidak banyak yang membuat, hanya 6 partai pada tahun 2004 yang membuatnya dan tahun 2009 hanya 9 partai yang memasukkan laporan keuangan. Padahal ini dimandatkan oleh undang-undang yang masih berlaku pada saat studi ini dibuat yaitu UU No. 2/2009 tentang Partai Politik. Laporan yang ada tidak memenuhi sistem pelaporan keuangan yang sesuai standar akuntansi. Sementara itu, standar akuntansi yang ada, yaitu PSAK 45, merupakan standar akuntansi keuangan yang dibuat IAI untuk organisasi nirlaba yang juga dipakai untuk partai politik. PSAK 45 ini tidak cukup mengakomodir karakteristik partai politik yang berbeda dengan organisasi nirlaba lain. Oleh karena itu, studi ini merekomendasikan adanya modifikasi atau pedoman khusus standar akuntansi keuangan untuk partai politik. Oleh Karena itu bahasan tulisan ini meliputi: (1) Dasar Pemikiran; (2) Skandal Keuangan; (3) Dasar Hukum; (4) Akuntabilitas; (5) Partai Yang Berkuasa; (6) Kesimpulan.

\section{DASAR PEMIKIRAN}

Karakter utama partai politik adalah faktor kekuasaan yang dimilikinya dan perannya dalam mewakili rakyat. Tujuan akhir dari partai politik adalah mendapatkan mandat dari konstituennya untuk memegang kekuasaan lewat cara-cara demokratis, yaitu lewat Pemilihan Umum. Dengan demikian partai dapat menempatkan individu pemimpinnya di parlemen atau di eksekutif dan dapat melaksanakan kekuasaan yang dipegangnya sesuai dengan ideologi yang dianutnya serta program yang dibuatnya (Thesing dan Hofmeisfer, 1995). Keberhasilan suatu partai politik diukur dengan banyaknya jumlah suara yang direbutnya lewat Pemilihan Umum.

Untuk mendapatkan suara pemilih maka partai akan menjual programnya dan kandidat-kandidatnya kepada pemilih lewat kegiatan kampanye. Pada kampanye ini maka banyak sekali janji janji yang diberikan partai sehingga agar pemilih percaya bahwa partai dialah yang terbaik dan berhak memegang kekuasaan negara. Apabila-dia menang maka ada dua jalur kekuasaan yang dipegang partai politik, yaitu jalur pengambil keputusan (eksekutif) dan jalur pembuat kebijakan (legislatif). Dari kedua jalur inilah partai politik dapat membuat suatu keputusan dengan mengatasnamakan rakyat. Setiap keputusan yang dibuat oleh partai politik akan memiliki dampak yang sangat sebuah partai politik tidak 
dipengaruhi oleh kepentingan kepentingan kelompok tertentu adalah dengan membatasi sumber dana yang boleh diterimanya, menciptakan sistem yang transparan dan bertanggunggugat, dalam hal pencatatan mengenai sumber dana tersebut. Pembatasan itu berbeda antara satu negara dengan negara lainnya. Pada umumnya pembatasan terjadi pada jumlah dana yang boleh diterima dari individu dan perusahaan, apakah boleh mengutip iuran anggota, ataukah boleh menerima subsidi dari pemerintah, dan sebagainya.

Seluruh sumbangan harus tercatat lengkap dengan identitas penyumbang. Sumbangan-sumbangan ini termasuk yang berbentuk natura, nilai setara kasnya harus dilaporkan dalam laporan keuangan. Dari laporan keuangan yang dihasilkan, kita bisa melihat apakah ada sumbangan-sumbangan yang berasal dari kelompok- kelompok tertentu dengan jumlah yang sangat besar. Juga kita bisa melihat dari penggunaan dananya, apakah cukup mewakili penerimaan dana "resmi" ataukah ada penerimaanpenerimaan khusus yang tidak tercatat. Skandal keuangan perusahaan Enron di Amerika Serikat membuka kenyataan kepada publik bahwa sebagian besar anggota Kongres dan Senat Amerika menerima sumbangan dari perusahaan tersebut. Informasi ini dapat diketahui oleh publik karena sistim pelaporan keuangan partai politik yang transparan dan bertanggunggugat di Amerika Serikat. Hal yang berbeda terjadi di Indonesia. Kasus dana Bulog yang dipakai untuk Jaring Pengaman Sosial (JPS) yang melibatkan AkbarTanjung sampai sekarang tidak bisa ditelusuri apakah dana tersebut masuk ke rekening Golkar atau ke rekening Yayasan Raudhatul Jannah. Dalam laporan keuangan Golkar yang kami pelajari, tidak ada sama sekali referensi kepada dana-dana publik yang diterima oleh Golkar yang pada saat itu memegang kekuasaan pemerintah. Proses pengadilan pun seolah-olah dibatasi hanya kepada tiga orang tersangka dan tidak melibatkan akuntabilitas keuangan dari Partai Golkar itu sendiri.

Hal lain yang perlu diperhatikan dalam partai politik adalah cara partai tersebut memenangkan Pemilu dan mendapatkan luas terhadap harkat hidup orang banyak. Dengan demikian partai politik harus sangat berhati-hati dalam setiap gerak langkahnya dan harus memastikan bahwa setiap tindakan yang dilakukan adalah demi masyarakat banyak, bebas dari politik uang dan pengaruh kelompok kepentingan (vested interest group). Dalam kenyataannya sulit sekali untuk melepaskan pengaruh kelompok kepentingan ini dari partai politik karena justru sifat dari partai politik itu yang hidup dari dukungan masyarakat.

Kelangsungan hidup partai politik sangat tergantung pada sumbangan yang diterimanya, baik dari anggotanya sendiri maupun dari simpatisannya. Sangat mudah bagi kelompok kepentingan untuk mempengaruhi partai politik melalui "sumbangan" yang diberikannya. Bahkan ada kecenderungan bahwa semakin populer suatu partai maka dia 
membutuhkan semakin banyak dana untuk dapat merealisasikan program dan targetnya. Hal ini menyebabkan adanya keterkaitan antara meningkatnya kekuasaan dan peningkatan kebutuhan akan dana yang menyebabkan etatisasi dan kapitalisasi dari partai politik (Schefold, 1995). Hal ini akan menyebabkan orientasi partai politik bukan lagi masyarakat luas tetapi kepada kepentingan donatur-donaturnya.

Kandidat partai politik tentu akan mempunyai sikap membalas budi bagi orang atau kelompok yang memberikan sumbangan sangat besar bagi partai politiknya. Jika hal ini terjadi, partai politik tidak lagi mewakili kepentingan masyarakat banyak. Partai politik menjadi perpanjangan tangan dari kelompok-kelompok tertentu sementara setiap gerak langkah partai politik tetap berdampak luas bagi masyarakat banyak. Ini tentu akan mengancam eksistensi sistem demokrasi yang ingin kita bangun (Global Corruption Report, 2009).

Dengan demikian, cara terbaik untuk memastikan bahwa sebuah partai politik tidak dipengaruhi oleh kepentingan-kepentingan kelompok tertentu adalah dengan membatasi sumber dana yang boleh diterimanya, menciptakan sistem yang transparan dan bertanggunggugat, dalam hal pencatatan mengenai sumber dana tersebut. Pembatasan itu berbeda antara satu negara dengan negara lainnya. Pada umumnya pembatasan terjadi pada jumlah dana yang boleh diterima dari individu dan perusahaan, apakah boleh mengutip iuran anggota, ataukah boleh menerima subsidi dari pemerintah, dan sebagainya.

Seluruh sumbangan harus tercatat lengkap dengan identitas penyumbang. Sumbangan-sumbangan ini termasuk yang berbentuk natura, nilai setara kasnya harus dilaporkan dalam laporan keuangan. Dari laporan keuangan yang dihasilkan, kita bisa melihat apakah ada sumbangan-sumbangan yang berasal dari kelompok-kelompok tertentu dengan jumlah yang sangat besar. Juga kita bisa melihat dari penggunaan dananya, apakah cukup mewakili penerimaan dana "resmi" ataukah ada penerimaan-penerimaan khusus yang tidak tercatat.

\section{SKANDAL KEUANGAN}

Skandal keuangan perusahaan Enron di Amerika Serikat membuka kenyataan kepada publik bahwa sebagian besar anggota Kongres dan Senat Amerika menerima sumbangan dari perusahaan tersebut. Informasi ini dapat diketahui oleh publik karena sistim pelaporan keuangan partai politik yang transparan dan bertanggunggugat di Amerika Serikat. Hal yang berbeda terjadi di Indonesia. Kasus dana Bulog yang dipakai untuk Jaring Pengaman Sosial (JPS) yang melibatkan Akbar Tanjung sampai sekarang tidak bisa ditelusuri apakah dana tersebut masuk ke rekening Golkar atau ke rekening Yayasan 
Raudhatul Jannah. Dalam laporan keuangan Golkar yang kami pelajari, tidak ada sama sekali referensi kepada dana-dana publik yang diterima oleh Golkar yang pada saat itu memegang kekuasaan pemerintah. Proses pengadilan pun seolah-olah dibatasi hanya kepada tiga orang tersangka dan tidak melibatkan akuntabilitas keuangan dari Partai Golkar itu sendiri. Hal lain yang perlu diperhatikan dalam partai politik adalah cara partai tersebut memenangkan Pemilu dan mendapatkan suara. Pada dasarnya pemilih akan memilih partai politik tertentu dengan melihat apakah partai tersebut dapat mewakili aspirasinya. Pemilih juga melihat apakah calon-calon legislatif dan calon-calon pemimpin partai tersebut adalah orang-orang yang dikenal mempunyai kemampuan, kredibilitas dan integritas tinggi. Di banyak tempat di negara berkembang dengan budaya yang paternalistik dan tingkat pendidikan yang rendah, maka para pemilih akan mengikuti pemimpin agama, adat atau tokoh-tokoh masyarakat di sekitar kehidupannya untuk menentukan partai pilihannya. Sehingga partaipartai politik dalam kampanye akan berlomba-lomba memperkenalkan ide-ide, gagasangagasan atau program-programnya kepada masyarakat luas.

Tetapi suatu partai politik yang korup juga akan memakai segala cara untuk memenangkan Pemilu. Politik uang, yaitu dengan memberikan uang kepada pemilih atau tokoh-tokoh masyarakat sering menjadi modus operandi partai-partai politik untuk memenangkan Pemilu. Praktek-praktek "serangan fajar", yaitu mendatangi para pemilih pada saat subuh menjelang hari pemilihan, sering terjadi di negara-negara berkembang. Politik uang ini harus dilarang dan harus dicegah. Untuk itu maka pengeluaran keuangan partai politik harus dicatat sedetil mungkin dan harus dilaporkan dalam laporan keuangan. Partai politik juga sering memanfaatkan fasilitas publik untuk keuntungan partainya. Hal ini kemungkinan besar terjadi pada partai politikyang memegang kekuasaan pemerintahan. Fasilitas-fasilitas pemerintah misalnya kendaraan, biaya transportasi, biaya komunikasi, biaya perjalanan, dan lain-lain, yang seharusnya untuk melakukan pelayanan publik, sering sekali dipakai juga oleh partai politik untuk urusan-urusan partai. Hal ini harus dilarang, dan untuk itu maka laporan keuangan partai politik harus memisahkan dengan jelas mana dana-dana yang didapat dari fasilitas publik dan mana yang berasal dari dirinya sendiri.

Di dalam sistem demokratis, pendanaan partai politik ini diatur dengan rinci untuk mencegah penyalahgunaan kekuasaan partai politik oleh kelompok-kelompok kepentingan. Aturan-aturan yang ketat juga dibuat untuk mencegah praktek politik uang dalam Pemilu. Hampir semua negara mempunyai undang-undang yang mengatur sumber pendanaan, batas maksimum sumbangan, pengelolaan dan pelaporan keuangan partai politik. Batasanbatasan mana yang boleh dan mana yang tidak perlu juga diatur oleh undang-undang. Untuk menghindari dominasi orang atau kelompok di dalam partai politik ini maka dibatasi 
pula besarnya sumbangan yang dapat diberikan oleh individu dan perusahaan kepada partai politik. Selain itu, partai politik diwajibkan membuat laporan tahunan yang diaudit oleh akuntan publik setiap akhir tahun dan sebelum serta sesudah Pemilu.

Selain kegiatan partai politik sehari-hari, kegiatan kampanye juga memerlukan biaya yang besar dan dukungan masyarakat. Untuk itu maka sumber-sumber dana untuk kampanye serta batasan jumlah sumbangan biasanya diatur dalam undang-undang6 serta harus dilaporkan kepada publik dan diaudit oleh akuntan publik. Besarnya sumbangan untuk dana kampanye ini selalu merupakan hal-hal yang kontroversial di beberapa negara dan juga di Indonesia.

\section{DASAR HUKUM}

Pengaturan terhadap pengendalian politik uang sebenarnya dapat dijumpai dalam undang-undang yang mengatur partai politik yaitu Undang-undang No. 2 tahun 2009 dan undang-undang tentang Pemilihan Umum yaitu Undangundang No. 3 tahun 2009 dan dalam Keputusan KPU No. 2. 2009 b. Dalam undang-undang dan peraturan ini telah diatur: (1) Pembatasan terhadap sumber dana kampanye yaitu dari partai politik yang bersangkutan, pemerintah (APBN dan atau APBD), dan pihak-pihak lain yang tidak mengikat yang meliputi badan-badan swasta, perusahaan, yayasan atau perorangan; (2) Pelarangan untuk membentuk badan usaha dan menanamkan saham di badan usaha karena merupakan organisasi nirlaba; (3) Pembatasan jumlah sumbangan untuk masing-masing penyumbang, baik perorangan maupun perusahaan, yaitu sebesar Rp 15 juta untuk individu dan Rp 150 juta untuk perusahaan, semuanya dalam kurun waktu satu tahun; (4) Pertanggungjawaban keuangan partai politik ditetapkan melalui kewajiban partai politik untuk memelihara sumbangan yang terbuka untuk diaudit serta mencatat secara detil penyumbang; (5) Kewajiban menyampaikan daftar sumbangan beserta laporan keuangan kepada Mahkamah Agung (MA); (6) Menetapkan mekanisme pengawasan dan penjatuhan sanksi, baik sanksi administrasi maupun sanksi pidana, termasuk atas pelanggaran terhadap ketentuan keuangan partai politik; (7) Pembatasan jumlah maksimum dana kampanye lewat aturan yang dikeluarkan oleh Komisi Pemilihan Umum (KPU) yaitu sebesar Rp 110 milyar; (8) Dana kampanye tidak boleh berasal dari pihak asing; (9) Kewajiban melaporkan dana kampanye Pemilu 15 hari sebelum hari pemungutan suara dan 25 hari setelah hari pemungutan suara; (10) Kewajiban melaporkan laporan keuangan tahunan setiap akhir tahun; (11) Melaporkan laporan keuangan beserta daftar sumbangan kepada Mahkamah Agung. 
Untuk dasar hukum pelaporan dan audit partai politik, tertera secara khusus didalam: 1. Pasal 15 UU No.2 tahun 2009 tentang partai politik, yang menyatakan: (1) Partai politik wajib melaporkan daftar penyumbang beserta laporan keuangannya. (2) Laporan sebagaimana dimaksud ayat (1) sewaktu-waktu dapat diaudit oleh akuntan publik. 2. Pasal 49 UU No. 3 tahun 2009 tentang Pemilihan Umum: (1) Dana kampanye Pemilihan Umum diaudit oleh akuntan publik dan hasilnya dilaporkan oleh partai politik peserta Pemilu kepada KPU.

Dari kedua pasal tersebut, kami melihat bahwa tidak diatur secara jelas maksud dan bentuk laporan keuangan dimaksud, sehingga walaupun IAI memakai PSAK 45, tetapi Mahkamah Agung mengeluarkan format tersendiri. Format laporan keuangan yang ditetapkan MA tidak memenuhi syarat sebagai laporan keuangan (hanya melaporkan penerimaan dana, pengeluaran dana, dan sisa dana) bahkan tidak memenuhi PSAK 45 yang ditetapkan oleh IAI.

Terjadi ketidakseragaman dan ketidakcukupan informasi keuangan dalam laporan keuangan yang disampaikan oleh partai politik. Berdasarkan hasil kunjungan kami ke Mahkamah Agung tanggal 14 Mei tahun ini, sebagian besar laporan keuangan partai politik yang disampaikan ke Mahkamah Agung adalah penggunaan dana kampany tahun 2009. Sementara itu, untuk laporan keuangan tahunan hanya lima partai yang menyampaikan laporan keuangan tahun 2009 dan hanya satu partai yang menyampaikan laporan keuangan tahun 2009 (IFES, 2009). Sebagian dari partai yang menyerahkan laporan kepada Mahkamah Agung hanya mengirimkan Anggaran Dasar mereka, dan tidak ada laporan keuangannya.

Tampak jelas bahwa kemampuan pengendalian Mahkamah Agung terhadap partai politik masih lemah. Mahkamah Agung masih mengalami kesulitan untuk "memaksa" partai politik membuat laporan keuangan setiap tahun secara tepat waktu dan menyerahkannya kepada Mahkamah Agung. Padahal undang-undang jelas mewajibkan hal tersebut. Dari laporan-laporan tersebut, kami menemukan hal-hal sebagai berikut: (1) Laporan-laporan tersebut mengikuti Pedoman Akuntansi Keuangan dan Penyusunan Laporan Keuangan Partai Politik yang dikeluarkan oleh Mahkamah Agung, yaitu hanya merupakan laporan penerimaan dan pengeluaran dana. Laporan ini tidak memenuhi syarat untuk disebut sebagai laporan keuangan, dan tidak sebagaimana lazimnya sebuah laporan keuangan yang terdiri dari laporan posisi keuangan, laporan rugi laba, laporan aktivitas, dan laporan arus kas beserta catatan laporan keuangan yang menyertainya; (2) Ikatan Akuntansi Indonesia menetapkan bahwa untuk laporan keuangan partai politik dapat dipakai PSAK 45. Maka jika merujuk pada pedoman akuntansi yang dikeluar kan IAI, laporan-laporan tersebut tidak memenuhi standar yang dikeluarkan IAI; (3) Sistem dan prosedur akuntansi 
yang digunakan hanya terdiri dari buku kas umum, buku kas pembantu, dan buku kas. Laporan hanya disusun dengan dasar kas bukan akrual dan tidak akan dapat digunakan sebagai bahan penyusunan laporan keuangan selayaknya; (4) Laporan itu hanya merupakan laporan keuangan Dewan Pimpinan Pusat Partai, bukan merupakan laporan konsolidasi partai dari tingkat ranting, cabang, daerah dan wilayah.

\section{AKUNTABILITAS KEUANGAN}

Masalah terbesar dari partai-partai politik di Indonesia pada Pemilu 2009, terutama partai-partai baru, adalah masalah pembiayaan kegiatan kampanye Pemilu, termasuk biaya untuk calon anggota legislatif (caleg). Karena kesulitan ini maka banyak sekali caleg dari berbagai partai politik yang membiayai sendiri kampanyenya. Selain itu, ada beberapa partai yang mensyaratkan anggotanya yang ingin menjadi caleg untuk mengumpulkan uang dengan jumlah minimum agar dimasukkan sebagai caleg. Dana-dana ini tidak dilaporkan kepada bendahara partai sehingga tidak tercatat dalam catatan penerimaan dana.

Masalah lain yang kami temukan adalah bahwa laporan keuangan yang dilaporkan kepada KPU tidak cukup terbuka (tidak full disclosure) dan tidak cukup mewakili kegiatan partai tersebut secara nasional. Yang diaudit oleh auditor publik adalah hanya DPPnya saja, sedangkan cabang dan ranting tidak diaudit. Padahal ada banyak dana yang beredar di cabang, di ranting ataupun di caleg yang tidak dikelola oleh bendahara DPP, yang berarti dana-dana tersebut tidak tercatat sebagai pemasukan oleh DPP, sehingga tidak diaudit dan tidak dilaporkan ke publik. Lubang ini dipakai oleh partai untuk mengatasi batasan jumlah dana yang dapat diberikan oleh individu dan perusahaan.

Persoalan lain adalah bahwa ada banyak sumbangan yang berikan secara spontan oleh para pendukung partai politik baik dalam bentuk natura ataupun tunai. Sumbangan ini ada yang diberikan dalam bentuk menyediakan berbagai fasilitas, dukungan kampanye, atau pengeluaran uang tunai yang dikelola sendiri, dan sebagainya. Fasilitas yang disediakan misalnya transportasi, untuk mengangkut masa pada saat rapat akbar atau untuk calon legislatif dan presiden. Laporan sumbangan natura ini dilaporkan dengan sangat tidak memadai bahkan ada yang tidak melaporkan sama sekali. Beberapa contoh misalnya soal transportasi calon presiden. Hampir semua kandidat presiden partai-partai besar melakukan perjalanan kampanyenya dengan memakai helikopter. Kemudian dalam kendaraan seharihari memakai mobil mewah, yang tiba-tiba saja muncul dan dipakai oleh si kandidat padahal publik tahu bahwa mobil itu bukanlah kepunyaan sang kandidat. Tetapi dalam laporan keuangan, publik tidak dapat melihat secara jelas pos pengeluaran untuk membayar helikopter dan mobil mewah ini, padahal biayanya pasti sangat besar. 
Golkar misalnya hanya melaporkan biaya perjalanan kampanye hanya sebesar Rp 461.933.120 tahun 2009. Angka ini tentu tidak mewakili perjalanan petinggipetinggi dan caleg-caleg serta calon presiden Golkar yang sangat ekstensif pada waktu itu. Sumbangan natura lain yang tidak muncul di dalam laporan keuangan adalah biaya-biaya rapat raksasa. Biaya-biaya ini antara lain biaya pengerahan massa dalam bentuk pengangkutan (bus atau truk), membayar artis (penyanyi, pelawak, band, dan sebagainya), panggung, dan sebagainya. Selain itu, dana pembuatan bendera, poster, spanduk, dan iklan, hanya sedikit yang dilaporkan dalam laporan keuangan. Kalau dilihat dari intensifnya dan ekstensifnya penyebaran informasi dari partai-partai besar, maka dana tersebut secara logika awam pasti jauh lebih besar dari yang dilaporkan, tetapi yang muncul dalam laporan keuangan kampanye jauh lebih sedikit (ICW, 2009)

\section{PARTAI BERKUASA}

Untuk partai yang berkuasa, dalam hal ini Golkar, sangat sulit untuk menemukan dan membedakan mana biaya yang ditanggung rakyat, dipakai pejabat pemerintah untuk kampanye Golkar. Biaya perjalanan presiden, menteri, dan pejabat di bawahnya walaupun secara teori mereka sudah tidak boleh lagi berkampanye, namun tetap dapat melakukan pertemuan untuk kepentingan Golkar dalam perjalanan dinasnya. Selain itu, juga sangat sulit untuk mencegah dipakainya dana publik untuk kegiatan-kegiatan yang bersifat karitatif. Kasus dana JPS yang disalurkan lewat partai politik yang berkuasa pada saat itu, yakni Golkar, jelas-jelas telah melanggar etika dan aturan main kampanye, tetapi sangat sulit untuk dideteksi.

Banyak penyumbang tidak melaporkan nama dan alamatnya secara jelas. Bahkan menurut para auditor, banyak sumbangan yang hanya menerakan kata-kata "Hamba Allah" dalam kolom nama dan alamat penyumbang. Hal ini bisa dijadikan peluang untuk memberikan sumbangan melewati batas maksimum yang diizinkan undang-undang dengan memberikan sumbangan lebih dari satu kali dengan nama "Hamba Allah" tersebut. Tentu petinggi partai tahu siapa yang memberikan sumbangan ini.

Ada pinjaman dari pribadi yang melebihi batas maksimum sumbangan individu, namun pinjaman ini tidak dengan akta perjanjian kapan dibayar dan untuk berapa lama. Dugaan kami ini hanya digunakan sebagai taktik untuk menghindari batas maksimum sumbangan individu. Tidak ada partai yang melaporkan dana kampanyenya lebih dari batas maksimum dana kampanye yang ditetapkan KPU, yaitu sebesar Rp 110 milyar. Partai-partai kecil pada umumnya hanya melaporkan penggunaan keuangan dari jumlah dana kampanye 
yang diterima dari pemerintah yaitu sebesar Rp 150 juta saja atau yang Rp 1 milyar saja. Mungkin mereka tidak berhasil menggalang dana dari publik, namun ada juga yang bersikeras menyatakan bahwa kewajiban mereka membuat audit hanyalah sebatas audit untuk dana yang mereka terima dari pemerintah saja.

Hampir semua auditor yang mengaudit dana kampanye Pemilu 2009 tidak dapat mengeluarkan opini mengenai pengelolaan keuangan partai politik peserta kampanye Pemilu. Hal ini disebabkan karena partai-partai tidak mempunyai catatan keuangan yang memadai dan memenuhi standar akuntansi yang dipakai umum, terutama di kantor-kantor cabang dan ranting. Pencatatan yang baik hanya ada di bendahara DPP. Ini merupakan kelemahan tetapi dapat pula dipakai sebagai taktik untuk menghindar dari batasan-batasan yang disebutkan di atas. Partai politik tidak menyampaikan laporan keuangan yang standar, sebagaimana yang disampaikan ke MA dan KPU, karena: (1) Didalam UU Partai Politik tidak ada kewajiban partai politik menyampaikan laporan keuangan (dengan kata lain didalam UU Partai Politik tidak ada kewajiban partai politik menyampaikan laporan keuangan sesuai standar); (2) Standar akuntansi yang ada tidak cukup menjadi pedoman bagi partai politik.

Semua laporan audit ini dilaporkan ke Mahkamah Agung, dan disimpan di Mahkamah Agung. Tidak ada tindak lanjut dalam bentuk penelitian apakah laporan tersebut benar sesuai dengan kenyataan, apakah ada pelanggaran-pelanggaran, dan sebaginya. Status laporan audit yang tidak memberikan opini kemudian tidak ditindaklanjuti oleh Mahkamah Agung untuk ditelusuri lebih jauh. Mahkamah Agung tidak mempunyai tim yang dapat menelusuri dan menindaklanjuti hasil audit laporan keuangan partai-partai ini. Standar laporan partai politik adalah menggunakan PSAK 45 yang dikeluarkan oleh IAI, yaitu standar akunting yang dikeluarkan untuk organisasi nirlaba. Dari laporan keuangan yang ada maka persoalan-persoalan yang dikemukakan di atas tidak terekam dengan baik. Tidak terekamnya karakteristik partai politik bukan hanya tidak dicatat, tetapi menurut pendapat kami, PSAK 45 ini memang tidak memadai untuk merekam hal-hal yang diatur dalam UU Pemilu dan UU Partai Politik.

Keterbatasan pada pedoman akuntansi keuangan dan penyusunan laporan keuangan ini mengakibatkan lemahnya sarana yang dapat dipergunakan sebagai mekanisme akuntabilitas keuangan dan transparansi keuangan. Keterbatasan ini mengakibatkan tidak terkendalinya keuangan partai politik yang pada gilirannya tidak mampu mencegah bahkan mengurangi praktek politik uang. Kelemahan sistem akuntansi dan pelaporan keuangan ini diperparah dengan tidak adanya kewajiban untuk mempublikasikan laporan keuangan partai politik kepada masyarakat secara luas. Dengan demikian, masyarakat sebagai 
stakeholder utama partai politik tidak dapat menggunakan laporan keuangan tersebut sebagai alat untuk mengontrol penyalahgunaan keuangan partai politik dan tidak mengetahui sumber keuangan dan pengalokasiannya. Karena itu pula, keterbukaan partai politik dalam hal keuangan yang merupakan informasi penting bagi warga negara untuk menilai dan memutuskan dukungannya terhadap partai politik menjadi sulit diharapkan.

Kelemahan-kelemahan yang kami temukan di atas disebabkan juga karena pasalpasal dalam undang-undang yang mengatur keuangan ini sangat lemah dan sangat sedikit mengatur mengenai hal ini. Ada banyak kelemahan yang dipakai oleh partai untuk menghindari aturan-aturan tersebut. Kelemahan-kelemahan tersebut antara lain tidak ada batasan atau larangan mengenai jumlah dana yang boleh diterima dari pemerintah. Tidak ada juga larangan untuk tidak memakai fasilitas publik dalam melakukan kampanye bagi petinggi partai yang masih menjabat sebagai pejabat publik. Tidak ada kewajiban untuk melakukan pencatatan sumbangan dan fasilitas yang didapat pada tiap level manajemen partai, sehingga banyak sumbangan dalam bentuk tunai dan natura yang tidak tercatat. Tidak ada kewajiban untuk mencatat seluruh sumbangan yang dipakai untuk kepentingan partai ke dalam catatan keuangan partai yang dikelola sekjen dan bendahara. Tidak ada aturan yang memisahkan antara dana kampanye dan dana rutin partai.

\section{SIMPULAN}

Berdasarkan argumentasi yang diuraikan di atas, maka jelaslah bahwa perlu ada Standar Akuntansi khusus untuk partai politik. Sampai dengan saat ini, belum ada standar akuntansi keuangan, baik yang dikeluarkan oleh Ikatan Akuntan Indonesia sebagai wadah organisasi profesi akuntan Indonesia maupun oleh lembaga pengawas partai politik (Mahkamah Agung dan Komisi Pemilihan Umum), yang secara khusus dapat dijadikan dasar penyusunan laporan keuangan bagi partai politik.

Dengan dasar adanya perbedaan karakteristik, perbedaan kepentingan pemakai laporan keuangan dan adanya transaksi-transaksi khusus partai politik, diperlukan adanya standar akuntansi keuangan khusus yang mengatur pelaporan keuangan partai politik. Dengan penyempurnaan standar akuntansi keuangan ini diharapkan laporan keuangan partai politik dapat lebih mudah dipahami, memiliki relevansi, dapat diandalkan dan memiliki daya banding yang tinggi. Laporan keuangan yang dihasilkan dapat dipergunakan oleh para pengguna laporan keuangan dan tidak menyesatkan.

Dengan demikian, transparansi di bidang keuangan dapat diwujudkan yang pada gilirannya penyalahgunaan dan pelanggaran keuangan oleh partai politik serta politik uang dapat dicegah atau setidaknya dikurangi. Untuk membuat standar 
akuntansi partai poltik, pertama harus ditentukan terlebih dahulu siapa pengguna laporan tersebut. Setelah itu baru ditentukan bentuk dan jenis laporan, dan entitas laporan. Laporan keuangan ini merupakan laporan keuangan terkonsolidasi dari hierarki terendah sampai tertinggi.

\section{DAFTAR PUSTAKA}

Bastian, Indra, 2002. Akuntansi untuk LSM dan Partai Politik. Erlangga

Global Corruption Report, 2009. Kasus-kasus dana kampanye di negara lain dapat dilihat dalam Transparency International, terutama dalam halaman 144-196.

IFES, 2009. Studi Tentang Partai yang Melaporkan Laporan Keuangan Tahun 2009 ke Mahkamah Agung.

ICW, 2009: Mekanisme Keuangan Partai Politik dan Implikasinya Terhadap Proses Demokratisasi di Indonesia.

Schefold, Dian. 1995. "Background and Basic Principles of Financing of Political Parties", dalam Political Parties in Democracy.

Thesing, Josef. 1995. "Transformation, Democracy and Political Parties, The Role and Significance of Parties", dalam Political Parties in Democracy. Editor: Josef Thesing dann Wilhem Hofmeister. Konrad Adenauer Stiftung.

Undang- Undang No. 2 tahun 2009 tentang Partai Politik. Pasal 14

Undang- Undang No. 2 tentang 2009 tentang Partai Politik. Pasal 15

Undang- Undang No. 3 tahun 2009 tentang Pemilu. Pasal 48 dan 49 